\title{
Anticardiolipin IgG Antibody
}

National Cancer Institute

\section{Source}

National Cancer Institute. Anticardiolipin Ig G Antibody. NCI Thesaurus. Code C70990.

An IgG autoantibody directed ag ainst cardiolipin. It is associated with thrombosis, spontaneous abortion, and complications during labor. 